\title{
Hydrogeo chemistry and fluoride delineation of Southern periphery of Morel Basin in part of Jaipur Distt., Rajasthan,Indi
}

\author{
S.K.Maanju, \\ S.S.in Earth Science, Vikram University,Ujjain(M.P.)
}

\begin{abstract}
The southern periphery of Morel basin covers entire Chaksu block which falls in south of Jaipur city of Rajasthan State. Groundwater is only source to meet out domestic demand of water in this block. Groundwater occurs in unconfined condition in most of the part in the area of Chaksu block. Occurrence of high fluoride exceeding $1.5 \mathrm{ppm}$ in the groundwater of Chaksu block has been found in large number of villages of Chaksu block and delineation of fluoride occurring in groundwater of this block has also been undertaken. Defluoridation technique can be adopted in areas of high fluoride groundwater so that health hazards can be checked apart from adopting rainwater harvesting through various methods viz. roof top rainwater recharge method.
\end{abstract}

Key words: - Groundwater, Chaksu \&Fluoride

\section{INTRODUCTION}

Fluoride Problem in groundwater has drawn attention of all sections of society in recent years. India is among 23 Nations around the globe facing fluoride problem. An estimated 62 million people in India spread over in 17 states are affected with dental, skeletal and non-skeletal fluorosis and high fluoride locations are shown on map 1 which was prepared by C.G.W.B. Chaksu block falls in Morel Basin, which covers part of Jaipur district. Groundwater is only source to meet out domestic demand of water in entire Chaksu Block due to lack of perennial surface water reservoirs. Groundwater occurs in unconfined condition in most of the part in the area. Earlier no high fluoride was reported in the groundwater of this block but recently it has been published in local newspapers many times about occurrence of high fluoride exceeding 3ppm in the groundwater of many villages lying in the Chaksu block.

\section{Distribution of Fluoride}

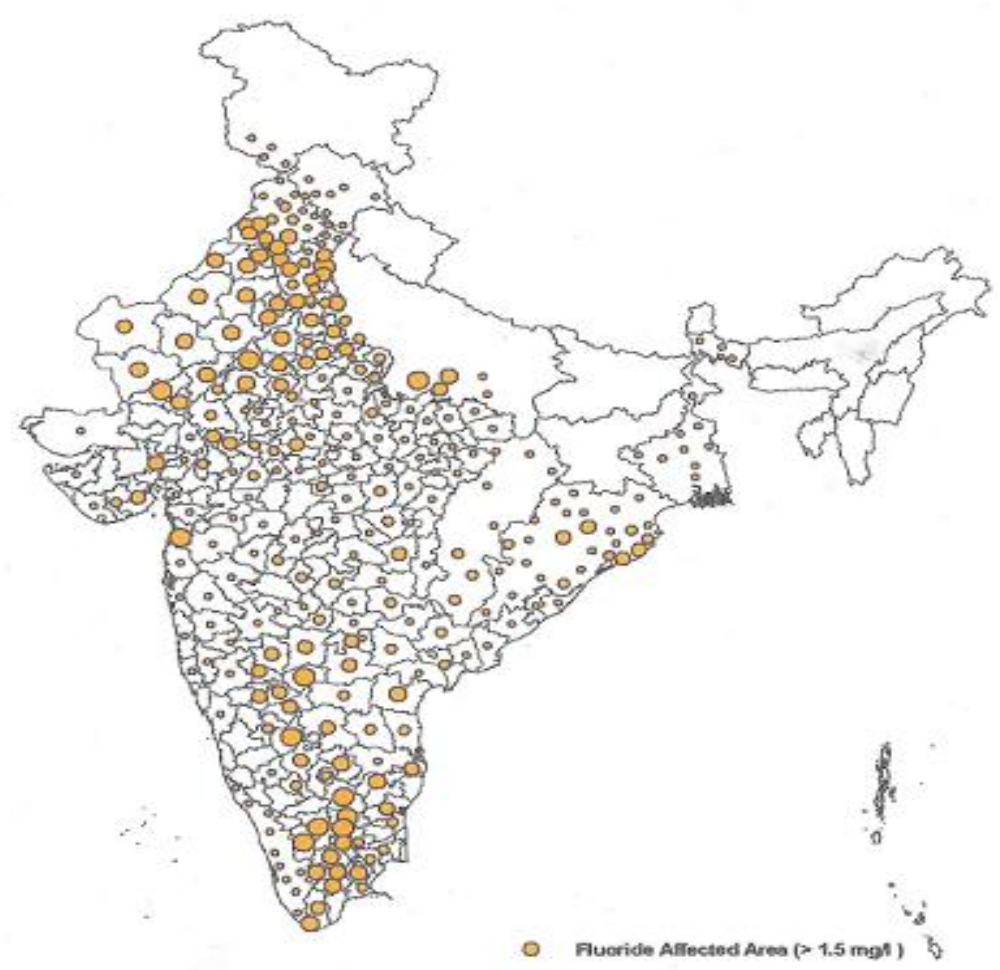

Map 1.(Source C.G.W.B.) 


\section{PHYSIOGRAPHY OF CHAKSU BLOCK}

The southern periphery of Morel basin covers entire southern part of Jaipur district which is comprised of an area of $11,061.41$ sq.km in State of Rajasthan. The district lies between $26^{0} 25^{\prime}$ to $27^{\circ} 51^{\prime} \mathrm{N}$ latitude and $74^{0} 55^{\prime}$ to $76^{\circ} 10^{\prime} \mathrm{E}$ longitude and is divided into 13 tehsils and 13 blocks and Chaksu is one of such block of this district which costitue soutern periphery of Morel basin. Out of total 279 villages of Chasku tehsil, 258 are habitated. Chasku is a town in Chasku tehsil. Chaksu block lies between latitude $26^{0} 29^{\prime}$ to $26^{\circ} 45^{\prime} \mathrm{N}$ and longitude $75^{\circ} 46^{\prime}$ to $76^{\circ} 13^{\prime} \mathrm{E}$ and covering an area of 811.92 sq.kms. as shown in Fig1 embodying 288 villages and 1 town as shown in figure 1.It has semi-arid climate with annual rainfall $572.42 \mathrm{~mm}$. An ephemeral Dhund river flows from $\mathrm{N}$ to $\mathrm{S}$ in the chaksu block. Chaksu block has an undulating physiography and irrigation and drinking water is met from groundwater in the area. From year 1984 to 2005, annually water level has declined by $0.62 \mathrm{~m}$ in alluvial aquifer and $0.59 \mathrm{~m}$ annually in hard rock aquifer.

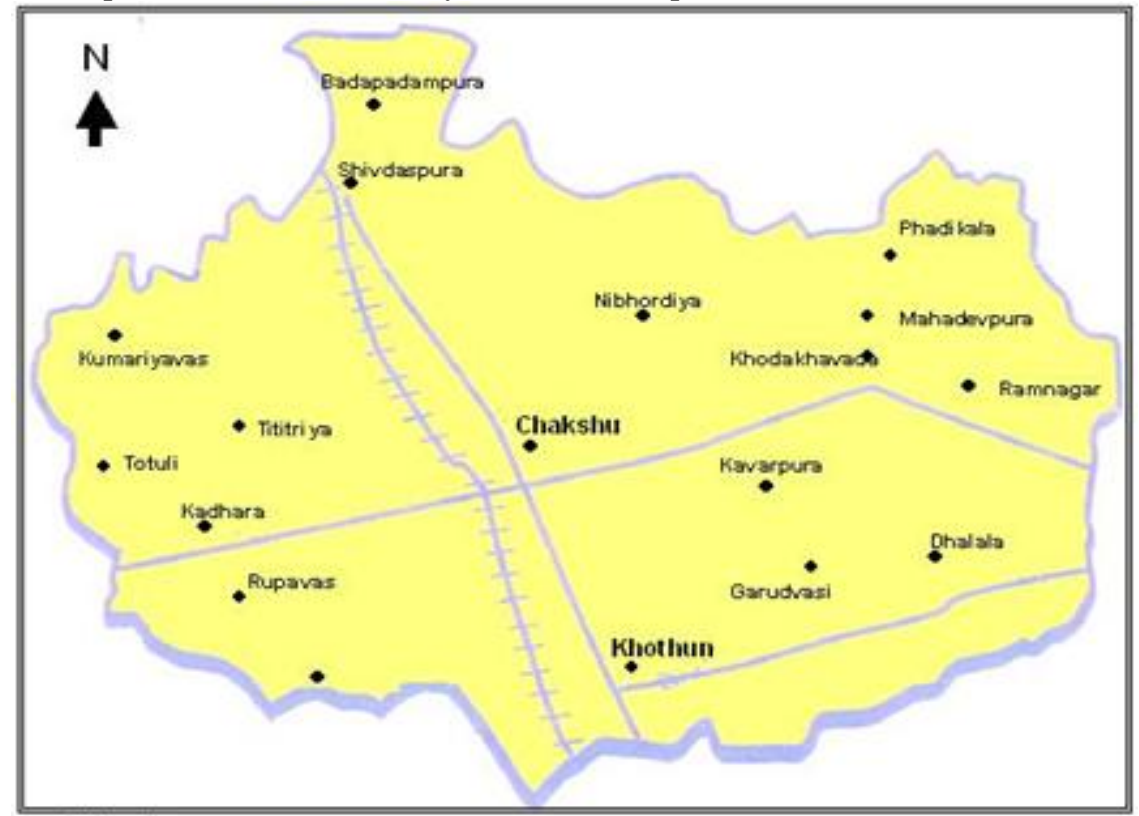

Fig. 1.

\section{HYDROGEOLOGICAL SUMMARY OF CHAKSU BLOCK}

This block covers an area of $811.92 \mathrm{Sq} . \mathrm{Km}$ and water bearing formations are Mica Schist and Older Alluvium. Two groundwater potential zones in the block are "Alluvium" \& "Hard rock" and are described as under:

The zone of alluvium covers an area of $552.06 \mathrm{Sq} . \mathrm{Km}$ and the main aquifer is semi consolidated older alluvium. The depth to water varies from 8.80 meters to 31.85 metres and the average yield of the wells is 70,000 liters per day and average discharge of the tube wells is $9.00 \mathrm{~m}^{3} / \mathrm{hr}$. The chemical quality of ground water is suitable for domestic purpose except high fluoride at certain locations. The present stage of ground water development is $162.49 \%$ and long-term trends of water levels have shown the significant decline, therefore, this zone has not been recommended for further ground water exploitation.

The zone of hard rock occupies an area of $177.30 \mathrm{Sq} . \mathrm{Km}$. The main aquifer is Schist and groundwater generally occurs in weathered zone and along schistosity, joints and fractured planes. The depth to water varies from 14.08metres to 21.98 metres and average yield of the wells is 52,000 liters per day and average discharge of the tube wells is $7.50 \mathrm{~m}^{3} / \mathrm{hr}$. The chemical quality of ground water is generally suitable for domestic purpose except high fluoride at certain locations. The present stage of ground water development is $188.90 \%$ and longterm trends of water levels have shown significant decline, therefore, this zone has not been recommended for further ground water exploitation. Water level depletion trend is shown in table 1. and water level of selected key wells is shown in table no. 2 .

Table 1:- Declining trend of water level of Chaksu Block

\begin{tabular}{|c|c|c|c|c|c|c|}
\hline \multirow[t]{2}{*}{ S. No } & \multirow[t]{2}{*}{ Type of aquifer } & \multicolumn{5}{|c|}{ Water level in meters } \\
\hline & & 1984 & 1995 & 1998 & 2004 & 2005 \\
\hline 1. & Alluvium & 10.16 & 13.98 & 12.94 & 21.14 & 22.47 \\
\hline 2. & Schist & 7.98 & 12.77 & 11.20 & 19.80 & 21.03 \\
\hline
\end{tabular}


Table-2 :- Water Level of Key Wells of Pre-Moonson 2006

\begin{tabular}{|l|l|l|}
\hline S. No. & \multicolumn{1}{|c|}{ Villages } & \multicolumn{1}{|c|}{ Pre-Moonson } \\
\hline 01 & Chandlai & 16.25 \\
\hline 02 & Chaksu & Dry \\
\hline 03 & Dehlala & 34.25 \\
\hline 04 & Gurwasa & 32.45 \\
\hline 05 & Hingonia & 18.20 \\
\hline 06 & Kadera & 26.65 \\
\hline 07 & Kohlya & Dry \\
\hline 08 & Kotkhawda & Dry \\
\hline 09 & Rupaheri & Dry \\
\hline 10 & Sheodaspura & 24.45 \\
\hline 11 & Titriya & 25.55 \\
\hline 12 & Tuntoli & 20.20 \\
\hline 13 & Garudwasi & Dry \\
\hline 14 & Akoriya & 24.30 \\
\hline 15 & Kothun & 22.15 \\
\hline 16 & Sanwasa (Sanwalia) & 15.25 \\
\hline
\end{tabular}

\section{GROUNDWATER QUALITY}

Groundwater quality is variable in different hydrological conditions and out of a total number of 288 villages of this block, 185 appear to have excess fluoride, 78 villages have excess nitrate, 70 villages have excess TDS and 27 villages have excess chloride. Chemical analysis results of selected key wells are shown in table 3. Fluoride delineation of the Chaksu block falling in southern periphery of Morel basin is shown on map 2

Table-3 Chemical analysis data of selected key wells

\begin{tabular}{|c|c|c|c|c|c|c|c|c|c|c|c|c|c|c|c|c|}
\hline $\begin{array}{l}\text { S. } \\
\text { No. }\end{array}$ & Location & $\begin{array}{l}\text { TDS } \\
\mathrm{Mg} / \mathrm{L}\end{array}$ & $\mathrm{pH}$ & $\mathrm{Na}^{+1}$ & $\mathrm{~K}^{+1}$ & $\mathrm{Ca}^{+2}$ & $\mathrm{Mg}^{+2}$ & $\mathrm{Cl}^{-1}$ & $\mathrm{SO}_{4}^{-}$ & ${ }_{2} \mathrm{CO}_{3}^{\circ}$ & ${ }_{1}^{\mathrm{HCO}_{3}}{ }^{-}$ & $\mathrm{NO}_{3}^{-}$ & $\begin{array}{l}\mathrm{F}^{-1} \\
(\mathrm{mg} / \mathrm{L})\end{array}$ & $\begin{array}{c}\mathrm{TH} \\
(\mathrm{mg} / \mathrm{L})\end{array}$ & $\mathrm{Na} \%$ & $\begin{array}{c}\mathrm{RS} \\
\mathrm{meq} / \mathrm{L}\end{array}$ \\
\hline 1 & Chandlai & 1004 & 8.2 & 11.4 & 0.29 & 1.10 & 5.90 & 9.2 & 2.10 & - & 6.20 & 0.32 & $\mathrm{Tr}$ & 350 & 61.0 & - \\
\hline 2 & Chaksu & 538 & 8 & 5.56 & 0.05 & 1.50 & 2.50 & 3.0 & 0.50 & 0 & 5.80 & 0.66 & 1.20 & 200 & 57.8 & 1.80 \\
\hline 3 & Dehlala & 1664 & 8 & 25.3 & 0.14 & 1.40 & 2.10 & 18.4 & 2.70 & 0 & 7.60 & 0.16 & 1.00 & 175 & 87.4 & 4.10 \\
\hline 4 & Gurwara & 1542 & 8.6 & 23.5 & 0.13 & 1.20 & 2.40 & 17.6 & 2.40 & 1.20 & 5.20 & 0.16 & 6.40 & 180 & 86.3 & 2.80 \\
\hline 5 & Hingonia & 1713 & 8.8 & 25.4 & 0.27 & 0.80 & 2.60 & 8.2 & 2.40 & 2.80 & 8.20 & 5.32 & 2.60 & 170 & 87.4 & 7.60 \\
\hline 6 & Kadera & 1273 & 8.9 & 19.8 & 0.15 & 0.70 & 2.40 & 4.8 & 2.30 & 4.00 & 8.40 & 1.81 & 6.80 & 155 & 85.9 & 9.30 \\
\hline 7 & Kohlya & 2272 & 8.6 & 34.7 & 0.37 & 0.70 & 3.70 & 19.8 & 2.80 & 3.20 & 9.60 & 2.82 & 1.60 & 220 & 87.9 & 8.40 \\
\hline 8 & Kotkhaw & 1057 & 8.9 & 16.5 & 0.05 & 0.30 & 2.20 & 5.2 & 1.80 & 2.80 & 8.80 & 0.32 & 7.40 & 125 & 86.6 & 9.10 \\
\hline 9 & Rupaheri & 1528 & 8 & 24.5 & 0.07 & 0.70 & 1.30 & 10.0 & 2.40 & 0.0 & 14.20 & 0.48 & 3.60 & 100 & 92.2 & 12.20 \\
\hline 10 & $\begin{array}{l}\text { Sheodas- } \\
\text { pura }\end{array}$ & 1785 & 8.9 & 28.1 & 0.06 & 1.10 & 2.70 & 8.2 & 2.20 & 6.0 & 12.60 & 1.94 & 15.00 & 190 & 87.9 & 14.80 \\
\hline 11 & Titriya & 910 & 8.6 & 9.6 & 0.18 & 1.30 & 5.90 & 8.8 & 1.60 & 1.20 & 4.80 & 0.19 & $\mathrm{Tr}$ & 360 & 56.5 & -- \\
\hline 12 & Tuntoli & 2641 & 8.7 & 33.0 & 0.39 & 1.10 & 8.80 & 23.0 & 3.30 & 2.40 & 6.80 & 7.82 & 3.60 & 495 & 76.2 & -- \\
\hline 13 & $\begin{array}{l}\text { Garudwa- } \\
\text { si }\end{array}$ & 1310 & 8.8 & 19.8 & 0.04 & 0.90 & 2.20 & 10.4 & 2.50 & 2.40 & 7.00 & 0.55 & 3.60 & 155 & 86.3 & 6.30 \\
\hline 14 & Akoriya & 1389 & 8.7 & 21.5 & 0.06 & 0.60 & 3.00 & 11.6 & 2.50 & 1.60 & 8.20 & 0.26 & 2.30 & 180 & 85.4 & 6.20 \\
\hline 15 & Kothun & 1631 & 8.8 & 25.4 & 0.13 & 0.80 & 2.30 & 8.4 & 2.50 & 2.00 & 11.20 & 2.87 & 2.20 & 155 & 88.7 & 10.10 \\
\hline 16 & Sanwasa & 1402 & 7.8 & 17.8 & 0.07 & 1.60 & 6.20 & 10.6 & 2.20 & 0 & 12.20 & 0.48 & 2.00 & 390 & 69.3 & 4.60 \\
\hline
\end{tabular}




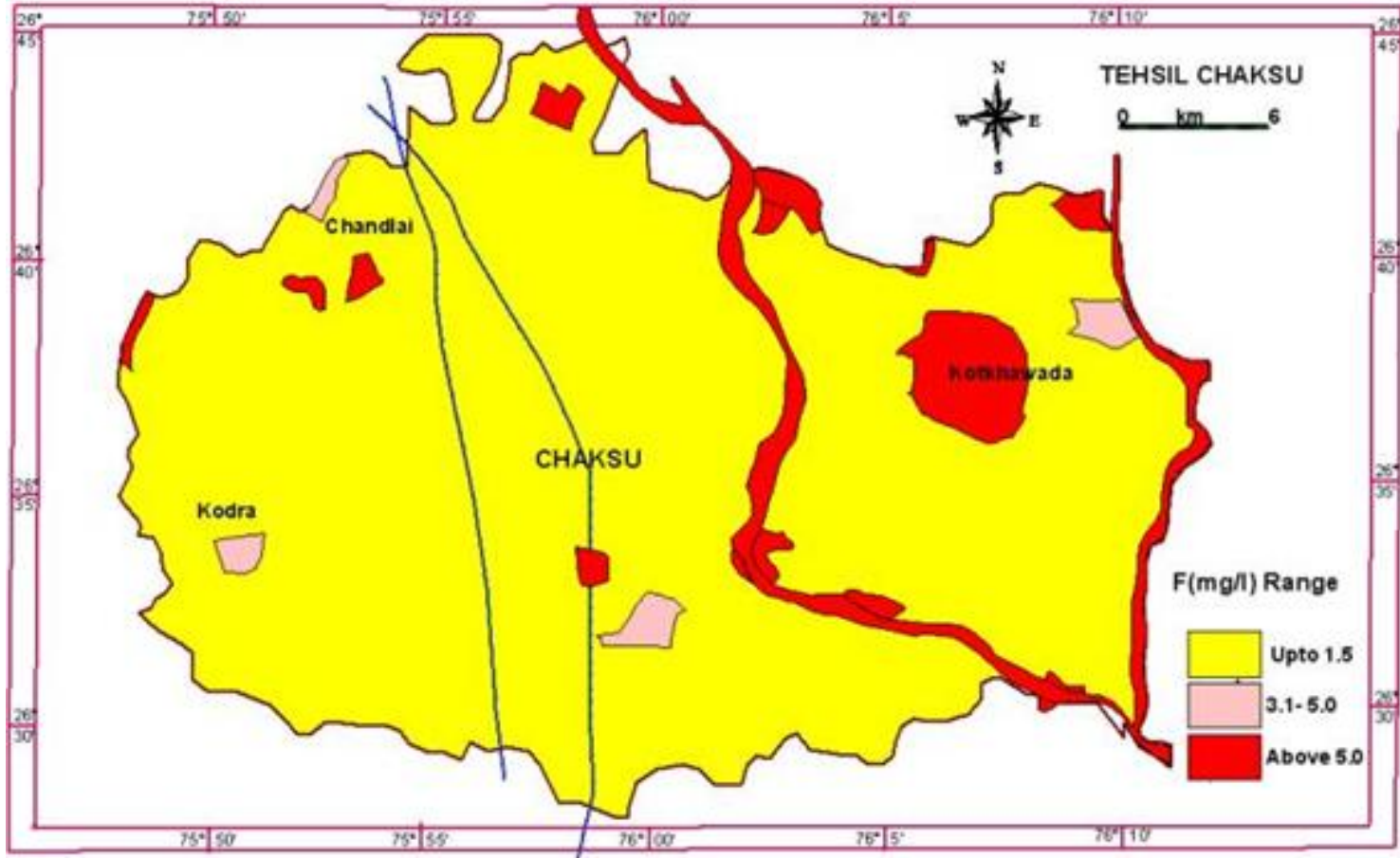

Map No. 2

\section{SOURCES OF FLUORIDE IN THE ENVIRONMENT}

Abundance of F in Sun, Earth's curst and meteorites is near about same. With Electronic Configuration $1 s^{2} 2 s^{2} 2 p^{5}$, elemental fluorine is just one electron short of the configuration of inert gases and as such it is most reactive of all the elements. Fluorite is the most widely distributed fluorine bearing mineral in the earth crust. Under supergene environment the element occurs as a highly mobile fluoride ion. Its mobility is severely restricted across a calcium barrier due to $\mathrm{CaF}_{2}$ precipitation. This leads to its enrichment in calcium rich rocks, like calcareous shale, limestones, dolomite, calcareous sandstones. Fluorine in igneous rocks- in magmatic rocks topaz, apatite and fluorite contain fluorine. The more evolved a rock is the higher is its F content. In apatite, fluorine content increases with increase in silica the rock. The F content of biotite is more in highly evolved granites compared to biotites occurring in lesser evolved Gabbros. Average fluorine content in ultramafic rock is $100 \mathrm{ppm}$, intermediate rocks- $400 \mathrm{ppm}$ and granitoids- $800 \mathrm{ppm}$. Average F content of basalts is $450 \mathrm{ppm}$. Fluorine during weathering- Fluorite is dissolved slowly by circulating waters. In soil profile decreasing F content with increasing distance from the parent rock is observed. Under acidic circulating solution F is readily adsorbed in clay structure. Average F content of soils ranges from 90 to $980 \mathrm{ppm}$. In semi-arid climates fluoride migration is inhibited during the summer due to higher calcium and low TDS in waters. During post monsoon, the mobility is enhanced due to low calcium distribution. Fluorine in sediments- Fluorine is the most abundant halogen in sedimentary rocks. The average fluorine content in different sedimentary rocks is shown below in table number 5 .

\begin{tabular}{|l|l|l|}
\hline \multicolumn{1}{|c|}{ Rocks } & \multicolumn{1}{c|}{ Range in ppm } & Avg. in ppm \\
\hline Limestone & Upto 1210 & 220 \\
\hline Dolomite & $110-400$ & 260 \\
\hline Sandstone & $10-110$ & 200 \\
\hline Shale & $10-7600$ & 940 \\
\hline Volcanic ashes & $100-2900$ & 750 \\
\hline Oceanic Sediments & $100-1600$ & 730 \\
\hline
\end{tabular}

(After Fleischer \& Robinson,1963)

\section{CONCLUSION}

The chemical quality of ground water is generally suitable for domestic purpose except high fluoride at certain locations. Since fluoride concentration has increased due to high overdraft of ground water in Chaksu block, therefore, it is suggested that artificial recharge of groundwater is essential for dilution of fluoride content in groundwater. The effective groundwater recharge methods are storm water management, recharge through abandoned and dried wells at local level as well as by adopting roof-top rainwater-harvesting which can 
popularized by providing financial support to the local residents in form of subsidy so that they can build their own rain water-harvesting structures in individual houses.

\section{REFERENCES}

[1] Bouwer, H. 1978 Ground water Hydrology,MC GrowHill, New-York

[2] Foster,M. D. 1942. Chemistry of Ground water in hydrology MC Grow Hill, New-York

[3] Garg, S.P. 1984 Ground water and tube wells Oxford and IBH publication. Co. 2nd Edn. New Delhi.

[4] Heath, R.C. and Frenk, W. Trainer 1968, Introduction of Ground Water Hydrology. John willey

[5] Indian Standard Institute (ISD) 1986 Indian standard for drinking water.

[6] Internet

[7] Karanath, K.R. Groundwater assessment development and management. Tata Mc Graw Hill Publication Co. Ltd. New Delhi.

[8] Maanju, S.K. 1997: Ground water characteristic in part of Morel Basin around Jaipur Bhu-jal News, Ministry of Water Resources, Govt. of India.

[9] Maanju,S.K.1992.Hydrogeology and Hydrochemistry of part of Morel Basin,Jaipur District,Rajasthan,India.Un-published PhD Thesis,University of Rajasthan,India.

[10] Todd, D.K. 1980 Ground water Hydrology, John Willey \& Sons, New-York

[11] Tolman, C.F. Ground water. Mc Graw Hills, New- York.

[12] Un-published Report, brochures, handbills and pamphlet of Ground water Deptt., Govt of Rajasthan. 